\title{
Foraminiferal bioevents in the Upper Campanian to lowest Maastrichtian of the Middle Vistula River section, Poland
}

\author{
Danuta PERYT ${ }^{1, *}$ and Zofia DUBICKA ${ }^{2}$ \\ 1 Polish Academy of Sciences, Institute of Paleobiology, Twarda 51/55, 00-818 Warszawa, Poland \\ 2 University of Warsaw, Faculty of Geology, Żwirki i Wigury 93, 02-089 Warszawa, Poland
}

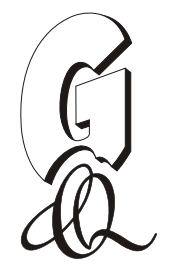

Peryt, D., Dubicka, Z., 2015. Foraminiferal bioevents in the Upper Campanian to lowest Maastrichtian of the Middle Vistula River section, Poland. Geological Quarterly, 59 (4): 814-830, doi: 10.7306/gq.1252

\begin{abstract}
The Upper Campanian-Lower Maastrichtian interval of the Middle Vistula River valley section records the following benthic foraminiferal bioevents in ascending stratigraphical order: LO of Globorotalites michelinianus, FO and LO of Globorotalites emdyensis ( = G. hiltermanni), $\mathrm{FO}$ of Bolivina incrassata, $\mathrm{FO}$ of Bolivinoides miliaris, $\mathrm{FO}$ of Angulogavelinella gracilis $(=A$. bettenstaedti), LO of Gavelinella monterelensis, FO of Osangularia navarroana, FO of Bolivina decurrens and FO of Neoflabellina reticulata. These events are recorded in very similar stratigraphic positions in the Lägerdorf-Kronsmoor succession (northern Germany) and in the succession of eastern England and, at least some of them, in eastern Europe. Accordingly they can serve as important markers for stratigraphic correlation across Europe. The FOs of the planktonic species, Rugoglobigerina milamensis, $R$. hexacamerata and $R$. pennyi, in the uppermost part of the "Inoceramus" redbirdensis Zone, are very close to the Campanian/Maastrichtian boundary as defined by inoceramid bivalves (Walaszczyk, 2004) and we propose these planktonic foraminiferal bioevents as a good proxy for this boundary in temperate regions.
\end{abstract}

Key words: Campanian/Maastrichtian boundary, foraminifera, bioevents, stratigraphic correlation, Middle Vistula River valley section.

\section{INTRODUCTION}

Foraminifera, especially planktonic forms, are one of the stratigraphically most important fossils in the Upper Cretaceous and are extensively used in interregional correlation due to their widespread distribution and high rate of evolution (e.g., Bolli, 1966; Robaszynski and Caron, 1995; Hardenbol et al., 1998). However, their usefulness is limited in many regions, mostly in high latitudes and in areas of shallow-shelf sedimentation (Bé, 1977; Premoli Silva and Sliter, 1999). The distribution of planktonic foraminifera in Cretaceous seas and oceans was, similarly to today, strongly influenced by sea depth, temperature, food supply and latitude. The diversity of modern planktonic foraminifera decreases from the tropics towards high latitudes by the progressive loss of warm-water and morphologically complex species. As a result, high-latitude assemblages are dominated by the most tolerant cosmopolitan forms with simple morphologies (Bé, 1977; Hemleben et al., 1989; Premoli Silva and Sliter, 1999). Too shallow sea can also limit the extent of planktonic foraminifera. The vertical range of planktonic foraminifera, related to their ontogeny, depends on water depth

\footnotetext{
* Corresponding author, e-mail: d.peryt@twarda.pan.pl
}

Received: April 17, 2014; accepted: September 15, 2015; first published online: September 16, 2015 and each species has its own bathymetric restrictions (Bé, 1977; Bailey and Hart, 1979; Caron and Homewood, 1983; Hemleben et al., 1989; Premoli Silva and Sliter, 1999).

During the Late Cretaceous, the area studied was a part of the European epicontinental sea and belonged to the Transitional Foraminiferal Province (Pożaryska and Peryt, 1979). This palaeogeographic location of the area and Late Cretaceous eustatic changes determined the diversity and taxonomic composition of its planktonic foraminiferal assemblages (Walaszczyk and Peryt, 1992; Dubicka and Peryt, 2012a). In general, these assemblages are taxonomically less diverse and contain fewer stratigraphically important forms than low-latitude assemblages, e.g. Tethyan. Unfortunately, the standard planktonic foraminiferal zonations (Hardenbol et al., 1998) are mainly based on low-latitude species of the family Globotruncanidae. Accordingly, these zonations are applicable in European epicontinental basins only in some intervals, e.g. in the Cenomanian, and are less useful in others, e.g. in the Campanian and Maastrichtian. As a result, some local zonations were established (e.g., Peryt, 1980; Dubicka and Peryt, 2012a).

The benthic foraminifera, which are often regarded as less useful in stratigraphy, can be very helpful, and often even more so than planktonic foraminifera, in the biostratigraphy of the European epicontinental Upper Cretaceous. In general, during the Late Cretaceous benthic foraminiferal assemblages were almost uniform throughout the European epicontinental basin and evolved and diversified comparatively quickly. Accordingly, 
they serve as a good tool for stratigraphy and regional/interregional correlations across Europe (e.g., Hiltermann, 1952; Hofker, 1952; Akimets, 1961; Koch, 1977; Rozumeiko, 1978; Hart et al., 1989; Odin, 1996; Bailey et al., 2009; Wilkinson, 2011; Dubicka and Peryt, 2014).

This work constitutes a part and continuation of the long-term and multi-disciplinary study on the stratigraphy of the Campanian-Maastrichtian transition of the Middle Vistula River section (see details in Walaszczyk, 2012). We describe planktonic as well as benthic foraminiferal bioevents which seem to have supraregional applications and compare them with the same events of other regions with well-established macrofaunal biostratigraphy.

\section{GEOLOGICAL SETTING}

The Upper Campanian-lowermost Maastrichtian sediments examined in this study are represented by a set of natural and artificial exposures scattered along the Middle Vistula River valley in central Poland. The study area belongs structurally to the Border Synclinorium (Kutek and Głazek, 1972; Pożaryski, 1997; Świdrowska, 2007; Voigt et al., 2008), i.e. to the Kościerzyna-Puławy Synclinorium of the most recent structural scheme (Żelaźniewicz et al., 2011). The interval studied is exposed between the villages of Dorotka, Dziurków and Kłudzie on the western bank of the river, and between the villages of Łopoczno and Kamień, on its eastern bank (Fig. 1 and Table 1). The upper Campanian-lowermost Maastrichtian succession is ca. $130 \mathrm{~m}$ thick and comprises mainly opoka (= siliceous limestone) (Walaszczyk, 2004). Walaszczyk (2004) distinguished five local lithostratigraphic units: Dorotka, Piotrawin and Dziurków opoka (the intervals with white, highly fossiliferous opoka) and the Solec and Wola Pawłowska opoka (the intervals with marly, brownish-grey, less fossiliferous opoka).

The studied interval represents Pożaryski's (1938) local zones from $n$ to $v$ and corresponds to Kongiel's (1962) Campanian $\alpha, \beta$ and $\gamma$ zones and an unnamed interval between the Campanian $\gamma$ Zone and the Maastrichtian $\alpha$ Zone. The following cephalopod zones in ascending order were distinguished in this interval by Błaszkiewicz (1966): Bostrychoceras polyplocum, Cirroceras donezianum, Nostoceras vistulae, Belemnella lanceolata lanceolata and Belemnella occidentalis. Błaszkiewicz (1980) replaced the Nostoceras vistulae Zone with the Nostoceras pozaryskii $(=N$. hyatti) Zone. Walaszczyk (2004) in the same interval distinguished eight inoceramid bivalve zones in ascending order: Cataceramus subcompressus, "Inoceramus" tenuilineatus, Sphaeroceramus pertenuiformis, "Inoceramus" altus, "Inoceramus" inkermanensis, Trochoceramus costaecus, "Inoceramus" redbirdensis, and Endocostea typica. Pożaryski (1938) placed the Campanian/Maastrichtian (C/M) boundary between his units $r$ and $s$. Kongiel (1962) shifted its position to the mid of unit $t$, and subsequently both Pożaryski (1966) and Błaszkiewicz (1966, 1980) accepted this revised position of the C/M boundary (Fig. 2).

After the ratification of the Campanian/Maastrichtian stage boundary at Tercis les Bains (Odin, 2001), the former lowest Maastrichtian belemnite zone in the Boreal Province, i.e. the Belemnella lanceolata Zone, falls within the uppermost Campanian (Christensen et al., 2000; Niebuhr et al., 2011; Keutgen et al., 2012; Machalski, 2012; Remin, 2012). According to Walaszczyk (2004), the C/M boundary (as defined in the stratotype section at Tercis) in the Middle Vistula River valley falls in the Kłudzie sections in the upper part of the "Inoceramus redbirdensis" Zone, which corresponds to the base of the Belemnella occidentalis Zone distinguished by Błaszkiewicz
(1980), i.e. at the top of Pożaryski's (1938) unit v. Remin (2012) put the Campanian/Maastrichtian boundary at the base of the Belemnella obtusa-B. vistulensis zone.

Based on calcareous nannofossils, Gaździcka (1978) included the Upper Campanian-lowermost Maastrichtian strata of the Middle Vistula River section into the Tetralithus (= Ceratolithoides) aculeus Zone, while Peryt (1980) subdivided this interval into two planktonic foraminiferal zones: Globigerinelloides multispinus and Rugoglobigerina pennyi (lower part).

Burnett et al. (1992) assigned strata from the Piotrawin Quarry represented by the Nostoceras pozaryskii ( $=N$. hyatti) Zone of Błaszkiewicz (1980) or the "Inoceramus" altus and "Inoceramus" inkermanensis inoceramid zones of Walaszczyk (2004) to nannofossil Subzone 22C. Peryt (2000) recognized in this profile the following zones: the miliaris/navarroana Partial Range Zone (upper part), the navarroana/cristata Partial Range Zone, the peterssoni/hiltermanni Concurrent Range Zone and the decurrens Interval Zone (lower part), i.e. benthic foraminiferal zones established by Schönfeld (1990) in the upper Campanian of the Lägerdorf section in northern Germany. Dubicka and Peryt (2012a) included the interval comprising the Piotrawin, Raj N, Kłudzie and Dziurków sections, i.e. the "I." altus, "I." inkermanensis, T. costaecus, "I." redbirdensis and Endocostea typica inoceramid zones, in their foraminiferal zones I to IV.

\section{MATERIAL AND METHODS}

Ninety-seven samples from the upper Campanian-lowermost Maastrichtian of 17 natural and artificial outcrops from the Middle Vistula River section were investigated. Washed residues for foraminiferal study were obtained from the rocks by disaggregation using $\mathrm{Na}_{2} \mathrm{SO}_{4}$ and sieving into $>63 \mu \mathrm{m}$ size fraction. The classification scheme used follows Caron (1985), Loeblich and Tappan (1987) and Pawlowski et al. (2013).

Since the present paper concerns the biostratigraphy we focussed on the most stratigraphically important foraminifera. We tracked mainly the ranges of planktonic foraminifera belonging to the genera Globotruncana and Rugoglobigerina, and those of the benthic genera Globorotalites, Gavelinella, Angulogavelinella, Bolivina, Bolivinoides and Neoflabellina. Representatives of these genera which have their first (FO) or last occurrences (LO) in the studied interval are discussed and their vertical ranges are compared to their stratigraphical ranges across Europe. The material was studied in detail and documented using a Philips XL20 SEM (Figs. 3 and 4). The morphological features crucial for diagnosis of the foraminifera studied are presented in the chapter "Taxonomy and comments".

\section{FORAMINIFERAL SUCCESSION}

PLANKTONIC FORAMINIFERA

In the succession studied, planktonic taxa compose from a few percent to almost $60 \%$ of the foraminiferal assemblages (cf. Peryt, 1980, 2000; Dubicka and Peryt, 2012a). More than 30 species of planktonic foraminifera are recorded (cf. Peryt, 1980). Their ranges, particularly their first and last occurrences, were strongly influenced by palaeoenvironmental changes. It is therefore impossible to apply the standard planktonic foraminiferal zonation for subdivision of this succession. Peryt (1980) included the studied interval in the Globigerinelloides 


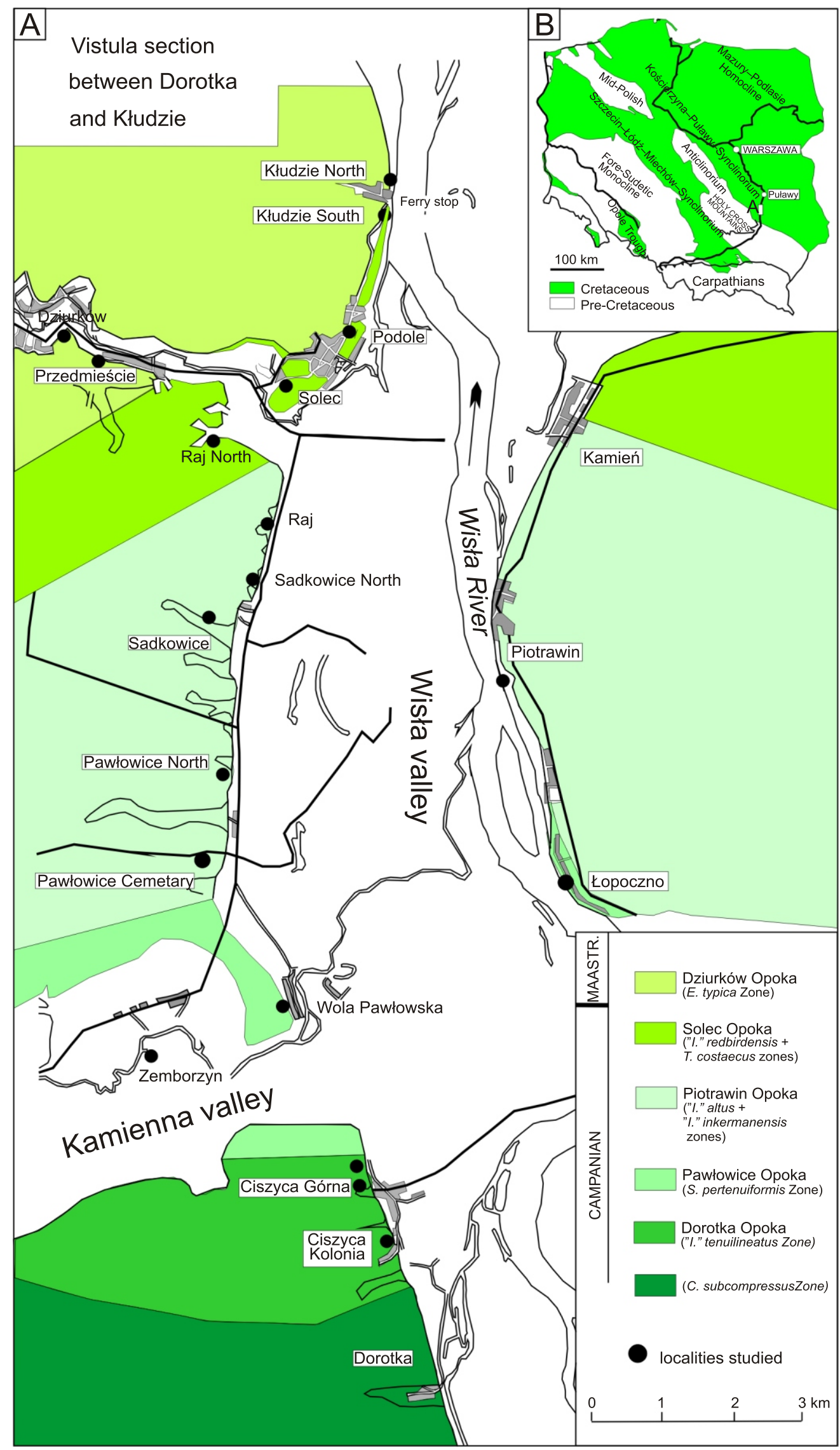

Fig. 1A - geological sketch map of the Upper Campanian through the Lower Maastrichtian in the Middle Vistula (Wisła) River valley section, central Poland (after Walaszczyk, 2004); B - geological pre-Cenozoic sketch map of Poland (after Pożaryski, 1974; Dadlez et al., 2002; Narkiewicz and Dadlez, 2008; Żelaźniewicz et al., 2011; simplified) 


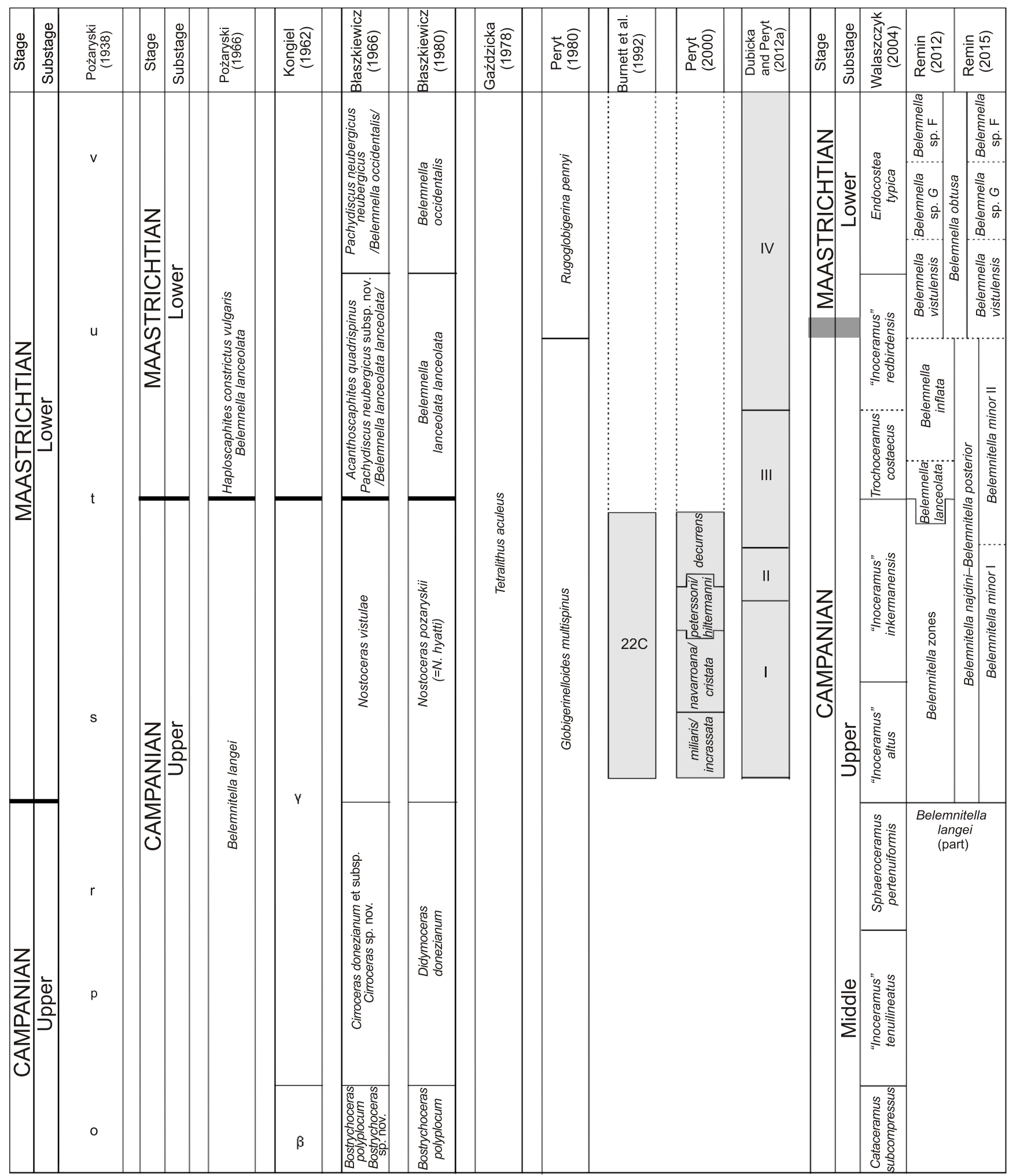

Fig. 2. History of stratigraphical studies of the Upper Campanian through the Lower Maastrichtian in the Middle Vistula River valley section, central Poland 
Characteristics of the sections studied in the Middle Vistula River valley

\begin{tabular}{|c|c|c|c|c|}
\hline Name & Exposure & Location & Exposed strata & $\begin{array}{l}\text { Inoceramid bivalve and cephalopod } \\
\text { biostratigraphy }\end{array}$ \\
\hline Dziurków & $\begin{array}{l}\text { small active } \\
\text { quarry }\end{array}$ & $\begin{array}{l}\text { eastern side of the village of } \\
\text { Dziurków }\end{array}$ & opoka (12 m) & $\begin{array}{l}\text { Endocostea typica Zone; upper Belemnella } \\
\text { occidentalis Zone; Belemnella obtusa Zone }\end{array}$ \\
\hline Kłudzie North & $\begin{array}{l}\text { small natural } \\
\text { outcrop }\end{array}$ & $\begin{array}{l}\text { western bank of the Vistula, } \\
\text { about } 30 \text { m north of the } \\
\text { Kłudzie ferry stop }\end{array}$ & $\begin{array}{l}\text { opoka }(9 \mathrm{~m}) \text { with } \\
\text { the marl layer } \\
\text { about } 6 \mathrm{~m} \text { above } \\
\text { the Vistula level }\end{array}$ & $\begin{array}{l}\text { "Inoceramus" redbirdensis Zone; upper } \\
\text { Belemnella lanceolata and lower B. } \\
\text { occidentalis zones; upper Belemnella } \\
\text { inflata and lower B. vistulensis zones }\end{array}$ \\
\hline Kłudzie South & $\begin{array}{l}\text { small natural } \\
\text { outcrop }\end{array}$ & $\begin{array}{l}\text { western bank of the Vistula, } \\
\text { about } 100 \mathrm{~m} \text { south of the } \\
\text { Kłudzie ferry stop }\end{array}$ & $\begin{array}{l}\text { opoka }(18 \mathrm{~m}) \text { with } \\
\text { marl layer in the } \\
\text { middle part }\end{array}$ & $\begin{array}{c}\text { "Inoceramus" redbirdensis and lowermost } \\
\text { E. typica Zone; upper Belemnella } \\
\text { lanceolata and lower B. occidentalis zones; } \\
\text { upper Belemnella inflata and B. vistulensis } \\
\text { zones }\end{array}$ \\
\hline Solec & $\begin{array}{l}\text { small natural } \\
\text { outcrop }\end{array}$ & $\begin{array}{l}\text { western part of the town of } \\
\text { Solec }\end{array}$ & $\begin{array}{l}\text { marly opoka } \\
\qquad(14 \mathrm{~m})\end{array}$ & $\begin{array}{c}\text { upper Trochoceramus costaecus and lower } \\
\text { "l." redbirdensis zones; Belemnella } \\
\text { lanceolata Zone; Belemnella inflata Zone }\end{array}$ \\
\hline Raj North & small quarry & $\begin{array}{l}\text { southern bank of the } \\
\text { Kreppianka River, a small } \\
\text { tributary of the Vistula river }\end{array}$ & marly opoka (9 m) & $\begin{array}{c}\text { upper Trochoceramus costaecus and lower } \\
\text { "l." redbirdensis Zone; Belemnella } \\
\text { lanceolata Zone; lower B. inflata Zone }\end{array}$ \\
\hline Kamień & $\begin{array}{l}\text { small natural } \\
\text { outcrop }\end{array}$ & $\begin{array}{l}\text { exposure in the road } \\
\text { escarpment }\end{array}$ & opoka & $\begin{array}{c}\text { base of the Trochoceramus costaecus } \\
\text { Zone; base of the Belemnella lanceolata } \\
\text { Zone }\end{array}$ \\
\hline Piotrawin & $\begin{array}{l}\text { large aban- } \\
\text { doned quarry } \\
\text { with three ex- } \\
\text { ploitation levels }\end{array}$ & $\begin{array}{l}\text { eastern bank of the Vistula, } \\
\text { about } 500 \mathrm{~m} \text { south of the } \\
\text { Piotrawin village }\end{array}$ & $\begin{array}{l}\text { opoka (approx. } \\
30 \mathrm{~m} \text { ) }\end{array}$ & $\begin{array}{l}\text { "I" altus and "I" inkermanensis zones; } \\
\text { Nostoceras pozaryskii (= N. hyatti) Zone }\end{array}$ \\
\hline Raj & $\begin{array}{l}\text { small aban- } \\
\text { doned quarry }\end{array}$ & $\begin{array}{c}100 \text { m south of the village of } \\
\text { Raj }\end{array}$ & opoka (7 m) & $\begin{array}{c}\text { upper "I" inkermanensis and Nostoceras } \\
\text { pozaryskii (= N. hyatti) zones }\end{array}$ \\
\hline Sadkowice North & $\begin{array}{l}\text { small aban- } \\
\text { doned quarry }\end{array}$ & $\begin{array}{l}\text { western bank of the Vistula } \\
\text { river, in the northern part of } \\
\text { the village }\end{array}$ & opoka (7 m) & $\begin{array}{l}\text { middle "I" inkermanensis Zone; upper } \\
\text { Nostoceras pozaryskii (= N. hyatti) Zone }\end{array}$ \\
\hline $\begin{array}{l}\text { Sadkowice } \\
\text { Quarry }\end{array}$ & $\begin{array}{l}\text { small aban- } \\
\text { doned quarry }\end{array}$ & $\begin{array}{l}\text { about } 100 \text { m west of the } \\
\text { main cross-road in the vil- } \\
\text { lage }\end{array}$ & opoka (10 m) & $\begin{array}{l}\text { lower "I" inkermanensis Zone; upper } \\
\text { Nostoceras pozaryskii (= N. hyatti) Zone }\end{array}$ \\
\hline Pawłowice North & $\begin{array}{l}\text { small natural } \\
\text { outcrop }\end{array}$ & $\begin{array}{c}\text { western bank of the Vistula } \\
\text { river, about } 1 \mathrm{~km} \text { north of the } \\
\text { main cross-road in the } \\
\text { village }\end{array}$ & opoka (6 m) & $\begin{array}{c}\text { upper "I" altus Zone; lower Nostoceras } \\
\text { pozaryskii (= N. hyatti) Zone }\end{array}$ \\
\hline $\begin{array}{l}\text { Pawłowice } \\
\text { Cemetery }\end{array}$ & $\begin{array}{l}\text { small natural } \\
\text { outcrop }\end{array}$ & $\begin{array}{l}\text { exposure at the northern end } \\
\text { of the village cemetery }\end{array}$ & opoka (5 m) & $\begin{array}{c}\text { lower "I" altus Zone; lower Nostoceras } \\
\text { pozaryskii (=N. hyatti) Zone }\end{array}$ \\
\hline Łopoczno & $\begin{array}{l}\text { small natural } \\
\text { outcrop }\end{array}$ & $\begin{array}{l}\text { exposure in the eastern bank } \\
\text { of the Vistula river }\end{array}$ & opoka (5 m) & $\begin{array}{c}\text { upper Sphaeroceramus pertenuiformis } \\
\text { Zone; upper Didymoceras donezianum } \\
\text { Zone }\end{array}$ \\
\hline Wola Pawłowska & $\begin{array}{l}\text { small operating } \\
\text { quarry }\end{array}$ & $\begin{array}{l}\text { exposure in the northern } \\
\text { bank of the Kamienna river, } \\
\text { a tributary of the Vistula, } \\
\text { about } 850 \text { m south of the } \\
\text { village bridge }\end{array}$ & marly opoka (7 m) & $\begin{array}{l}\text { lower Sphaeroceramus pertenuiformis } \\
\text { Zone; upper Didymoceras donezianum } \\
\text { Zone }\end{array}$ \\
\hline Ciszyca Górna & $\begin{array}{c}\text { small natural } \\
\text { outcrop }\end{array}$ & $\begin{array}{l}\text { exposure in the western } \\
\text { bank of the Vistula river }\end{array}$ & opoka (6 m) & $\begin{array}{l}\text { upper "I" tenuilineatus Zone; lower } \\
\text { Didymoceras donezianum Zone }\end{array}$ \\
\hline Kolonia Ciszyca & $\begin{array}{l}\text { small natural } \\
\text { outcrop }\end{array}$ & $\begin{array}{c}\text { exposure in the western } \\
\text { bank of the Vistula river, } \\
\text { beside the Leśne } \\
\text { Chałupy-Tarłów road }\end{array}$ & opoka (5 m) & $\begin{array}{l}\text { lower "I" tenuilineatus Zone; lower } \\
\text { Didymoceras donezianum Zone }\end{array}$ \\
\hline Dorotka & $\begin{array}{l}\text { small aban- } \\
\text { doned quarry }\end{array}$ & $\begin{array}{l}\text { exposure in the western } \\
\text { bank of the Vistula river, } 50 \\
\mathrm{~m} \text { north of the main road in } \\
\text { the village }\end{array}$ & opoka (7 m) & $\begin{array}{l}\text { Cataceramus subcompressus Zone; } \\
\text { Bostrychoceras polyplocum Zone }\end{array}$ \\
\hline
\end{tabular}

Inoceramid bivalve and cephalopod biostratigraphy after Walaszczyk (2004), Błaszkiewicz (1980) and Remin (2012)

multispinus and the Rugoglobigerina pennyi zones of the local planktonic foraminiferal zonation. In the lower part of the interval studied (Cataceramus subcompressus, "Inoceramus" tenuilineatus and lower part of the Sphaeroceramus pertenuiformis inoceramid zones), the planktonic foraminiferal assemblages show high diversity with common deep-water planktonic foraminifera: Contusotruncana fornicata, $C$. plummerae (Fig. 3Aa-Ab), C. patelliformis, Globotruncana ventricosa (Fig. 3Ba-Bb), G. rugosa (Fig. 3Ca-Cb), G. cf. aegyptiaca, G.mariae, G. bulloides, G. linneiana. Archaeoglobigerina blowi, A. cretacea and Pseudotextularia nuttalli (Fig. $3 \mathrm{Ha}-\mathrm{Hb}$ ) are also present in this interval. In the "Inoceramus" altus Zone, globotruncanids disappear almost completely. The interval comprising the "Inoceramus" altus, "l." inkernanensis, Trochoceramus costaecus and "I." redbirdensis inoceramid zones is characterized by low diversity planktonic foraminiferal assemblages dominated by Heterohelix and Globigerinelloides. This taxonomic impoverishment probably 

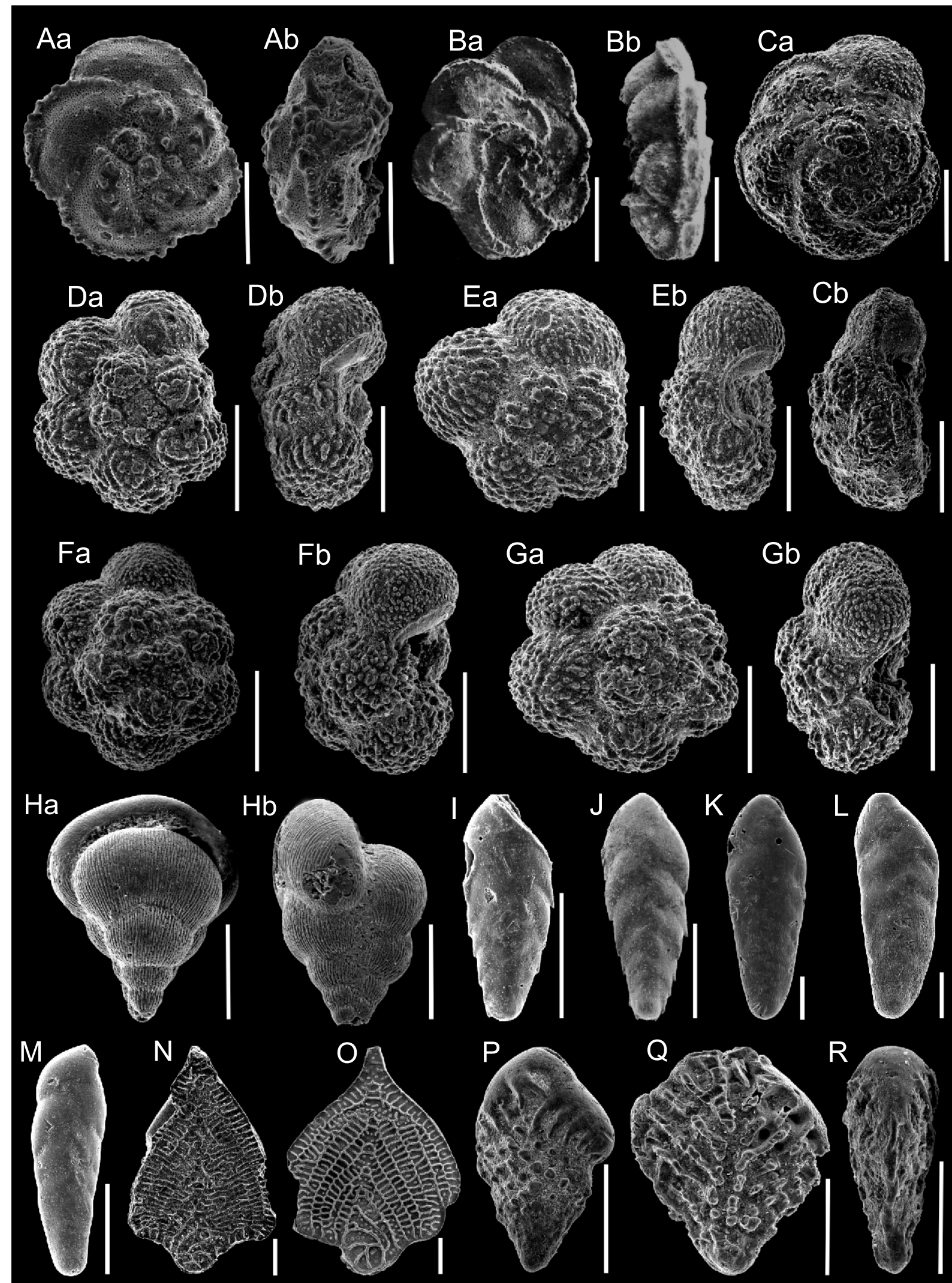

Fig. 3. Selection of significant benthic and planktonic foraminifera from the studied interval

Aa-Ab - Contusotruncana plummerae (Gandolfi), Ciszyca Górna, sample 1; Ba-Bb - Globotruncana ventricosa (White), Ciszyca Górna, sample 4; Ca-Cb - Globotruncana rugosa (Marie), Wola Pawłowska, sample 1; Da-Db - Rugoglobigerina hexacamerata Brönnimann, Kłudzie N, sample 3; Ea-Eb - Rugoglobigerina rugosa (Plummer), Kłudzie N, sample 3; Fa-Fb - Rugoglobigerina milamensis Smith and Pessagno, Kłudzie N, sample 3; Ga-Gb - Rugoglobigerina pennyi Brönnimann, Kłudzie N, sample 3; Ha-Hb - Pseudotextularia nuttalli (Voorwijk), Ciszyca Górna, sample 4; I, J - Bolivina decurrens (Ehrenberg): I - Raj N, sample 2, J - Sadkowice, sample 1; K-M - Bolivina incrassata Reuss: K - Kłudzie, sample 3, L - Raj, sample 5, M - Raj, sample 2; N - Neoflabellina praereticulata Hiltermann, Piotrawin, sample 5; O Neoflabellina reticulata (Reuss), Kłudzie, sample 3; $\mathbf{P}$ - Bolivinoides miliaris Hiltermann et Koch, Dorotka, sample 1; Q, R - Bolivinoides sp. transitional form from Bolivinoides miliaris Hiltermann et Koch to B. draco (Marsson), Kłudzie N, sample 3; scale bars - 200 mm 

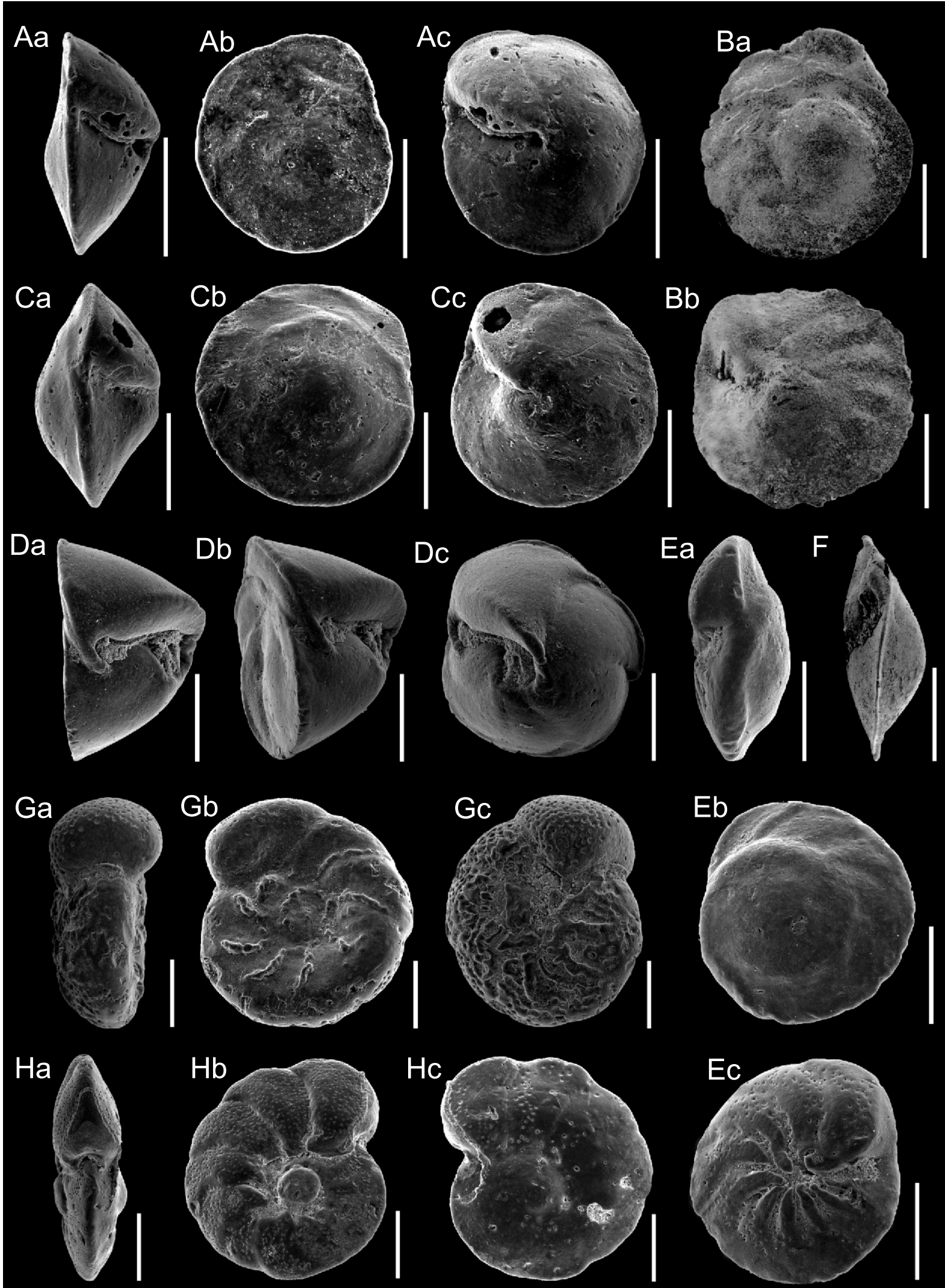

Fig. 4. Selection of significant benthic foraminifera from the studied interval

Aa-Ac, Ca-Cc - Globorotalites emdyensis Vasilenko, Ciszyca Górna, sample 1; Da-Dc - Globorotalites michelinianus (d'Orbigny), Wola Pawłowska, sample 3; Ba-Bb, F - Osangularia navarroana (Cushman), Piotrawin, sample 4; Ea-Ec - Angulogavelinella gracilis (Marsson), Kłudzie N, sample 14; Ga-Gc - Gavelinella clementiana (d’Orbigny), Dorotka, sample 1; Ha-Hc - Gavelinella monterelensis (Marie), Dorotka, sample 1; scale bars - $200 \mu \mathrm{m}$ 
reflects the latest Campanian-earliest Maastrichtian eustatic sea level fall (Dubicka and Peryt, 2012a). In the uppermost Campanian Rugoglobigerina rugosa appears. The lowest occurrence of the species is noted in the Raj North section, i.e. in the lower part of the Belemnella lanceolata lanceolata Zone sensu Błaszkiewicz (1980) and at the base of the Belemnella inflata Zone (Remin, 2012). At approximately this level, i.e. just below the traditional $B$. lanceolata Zone, the FO of Rugogolobigerina was reported from Norfolk, England (Hart et al., 1989; Hart and Świecicki, 2003). An abundant and taxonomically more diverse occurrence of Rugoglobigerina begins at the boundary marl at Kłudzie, i.e. within the "Inoceramus" redbirdensis inoceramid Zone. Rugoglobigerina is represented there by the following species: $R$. pennyi, R. milamensis, $R$. hexacamerata and $R$. rugosa. The predominance of Rugoglobigerina in planktonic foraminiferal assemblages is commonly noted in the Lower Maastrichtian of Poland, Ukraine (Dubicka and Peryt, 2012a) and Russia (Saratov Region Olferev et al., 2007, and northwestern Rostov Region Benyamovskiy et al., 2012). In the Zumaia section in northern Spain (Pérez-Rodríguez et al., 2012) $R$. rugosa, $R$. hexacamerata and $R$. pennyi occur below the Campanian/Maastrichtian boundary i.e. within the Rugoglobigerina rotundata Zone, below the base of the Pachydiscus neubergicus ammonite Zone. Accordingly, the appearance of Rugoglobigerina in the Vistula River section is an only local event and can be applied in only temperate regions.

Rugoglobigerina scotti was described from the Campanian/Maastrichtian boundary in the Tercis les Bains section (Arz and Molina, 2001). Odin et al. (2001) considered this species to be Rugoglobigerina cf. scotti (a transitional form) which cannot be useful for identifying the Campanian/Maastrichtian boundary. At Zumaia "true" Rugoglobigerina scotti has its lowest occurrence in the middle part of the Abathomphalus mayaroensis Zone in the uppermost Maastrichtian (Pérez-Rodríguez et al., 2012).

\section{BENTHIC FORAMINIFERA}

Based on the study of stratigraphically relevant benthic foraminiferal taxa we recognized thirteen foraminiferal bioevents. These events are discussed below in ascending stratigraphic order.

The LO of Gavelinella clementiana is recorded in the Dorotka outcrop, i.e. in the Cataceramus subcompressus inoceramid Zone and the Bostrychoceras polyplocum ammonite Zone. The LO of the species in Kronsmoor in NW Germany was recorded much higher, i.e. in the navarroana/cristata Zone, in the lower Micraster grimmensis/Cardiaster granulosus Zone (Schönfeld, 1990). In eastern England G. clementiana disappears within the interval of the co-occurrence of Globorotalites hiltermanni ( $=G$. emdyensis) and Bolivina incrassata (Hart et al., 1989), which is probably later than in the Middle Vistula River section. In the Tercis section, the highest occurrence of $G$. clementiana is recorded just above the Campanian/Maastrichtian boundary (Odin and Lamurelle, 2001), this being much higher than in all of the above-mentioned regions. Thus the LO of G. clementiana is clearly diachronous in epicontinental Cretaceous of Europe, which was also recognized by Watkins and Veltkamp (1994). It seems that $G$. clementiana was very sensitive to environmental changes, which precludes its use in supraregional correlations. In the Dorotka section, we also noticed the occurrence of Globorotalites emdyensis (= G. hiltermanni). Since this species has not been recorded in the stratigraphically lower Inoceramus
azerbaydjanensis-Inoceramus vorhelmensis inoceramid Zone of the Polish Lowland (Dubicka, 2015), its first appearance seems to be in the Cataceramus subcompressus inoceramid Zone and the Bostrychoceras polyplocum ammonite Zone. This position corresponds to the FO of Globorotalites emdyensis (= G. hiltermanni) recorded in the Lägerdorf-Kronsmoor succession, i.e. in the middle part of the Bostrychoceras polyplocum Zone.

In the lower part of the "Inoceramus" tenuilineatus and Didymoceras donezianum zones in the Ciszyca Kolonia section Bolivina incrassata and Bolivinoides miliaris have been recorded. Their actual FOs are probably stratigraphically lower than that, as we found these taxa in K. Pożaryska's archive sample named "Dorotka North", located in the northern part of the village of Dorotka. Similarly, in the Lägerdorf-Kronsmoor succession the FOs of these two taxa are placed very close to each other within a few metres, just below and above the F100 horizon and slightly above the FO of Globorotalites hiltermanni (Schönfeld, 1990). They are placed in the Bostrychoceras polyplocum Zone sensu Schulz et al. (1984). In eastern England, as well as in the southern North Sea Basin, the lowest records of all these species are also stratigraphically very close to each other, in the upper part of the traditional Belemnitella mucronata Zone (Hart et al., 1989; Hart and Swiecicki, 2003). Accordingly, the FOs of Globorotalites emdyensis (= G. hiltermanni), Bolivina incrassata and Bolivinoides miliaris appear to be stratigraphically relevant for correlation across Europe.

The LO of Globorotalites michelinianus is recorded in the Ciszyca Górna succession, i.e. in the Didymoceras donezianum ammonite Zone and in the "Inoceramus" tenuilineatus inoceramid Zone (Fig. 5). Hart et al. (1989) noted the LO of G. michelinianus in eastern England in the upper part of the traditional Belemnitella mucronata Zone within the lower part of the ranges of $G$. emdyensis (= G. hiltermanni) and Bolivinoides miliaris, as observed in the section studied. Thus, this foraminiferal event occurs in a similar stratigraphical position in both central and western parts of Europe.

The FO of Osangularia navarroana is recorded in the upper part of the Wola Pawłowska section, in the Sphaeroceramus pertenuiformis inoceramid Zone. At Kronsmoor, this species appears at $226.10 \mathrm{~m}$, defining the base of the navarroana/cristata Zone. It occurs in the uppermost part of the Belemnitella langei Zone and just below the FO of Angulogavelinella gracilis. Therefore, the first appearances of $O$. navarroana in the Middle Vistula River section and in Kronsmoor seem to occur in a similar stratigraphical position.

The temporary disappearance of Gavelinella monterelensis was recorded in the lowest part of the Pawłowice Cemetery section. A morphological equivalent of $G$. monterelensis were also observed in a Middle Maastrichtian interval of the Middle Vistula River section (Dubicka and Peryt, 2012b), as well as in the Vijlen Member in Belgium (Robaszynski et al., 1985). The disappearance of $G$. monterelensis (= Brotzenella monterelensis) were recorded in an approximately similar position in the Vishnevoe section, Saratov Region, Russia (Olferev et al., 2007). The event is located there in the Nalitovo Formation, above the FOs of Belemnitella langei langei, B. langei najdini and Belemnella licharewi, and below the FO of Belemnella lanceolata. Additionally, it is placed slightly below the LO of Globorotalites emdyensis (= G. hiltermanni), as in the Middle Vistula River section.

In the lowest part of the Pawłowice Cemetery section the first record of a "true" Angulogavelinella gracilis is observed. Early forms of $A$. gracilis which occur throughout the Łopoczno section (Sphaeroceramus pertenuiformis inoceramid Zone) are 


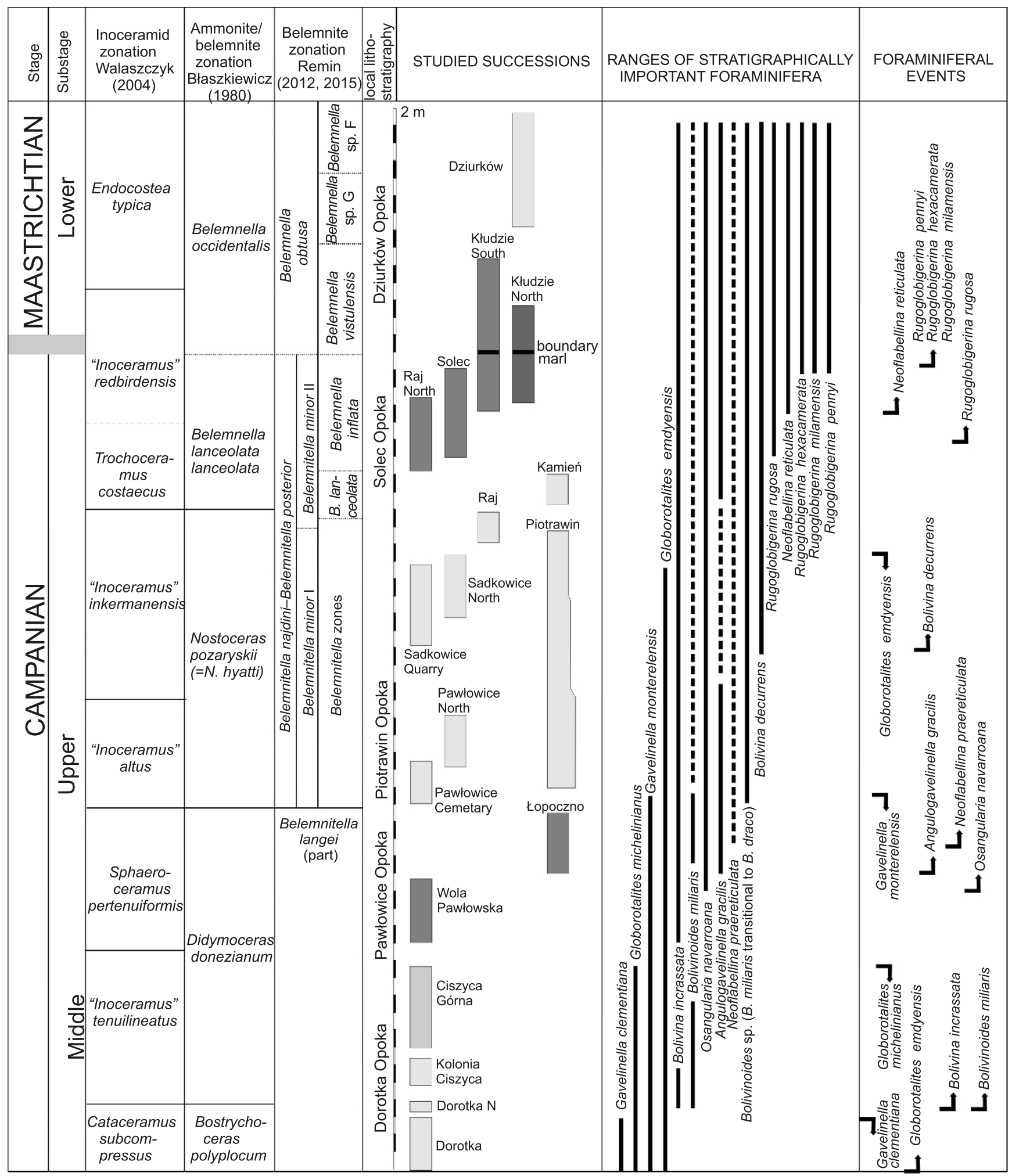

Fig. 5. Geological columns, stratigraphy and correlations of the sections studied 
characterized by a test with a flat trochospiral side. In the Wola Pawłowska section there is an absence of all morphotypes of $A$. gracilis. According to these foraminiferal data, the Wola Pawłowska succession should be shifted slightly lower than as indicated by Walaszczyk (2004), i.e. these two successions probably do not correlate. The interval with the co-occurrence of G. monterelensis, "true" $A$. gracilis and Neoflabellina praereticulata is represented in the Middle Vistula River section only in the lowest part of the Pawłowice Cemetery succession. It is better exposed in the Miechów Synclinorium in southern Poland. A precise stratigraphical position of the lowest record of A. gracilis (= A. bettenstaedti) was determined by Schönfeld (1990) at Kronsmoor, northwestern Germany where the species first appears at $231.30 \mathrm{~m}$ in the lower part of the navarroana/cristata Zone, close to the lower boundary of the Belemnitella langei Zone and the Micraster grimmensis/Cardiaster granulosus Zone, and just below the LO of G. hiltermanni and the FO of Bolivina decurrens. Therefore, the FOs of $A$. gracilis in the Middle Vistula River section and in the Kronsmoor succession seem to be equivalent.

The FO of Neoflabellina praereticulata recorded in the Middle Vistula River section in the Łopoczno section, Sphaeroceramus pertenuiformis inoceramid Zone, probably does not represent its actual FO. In general, $N$. praereticulata is a rare species in the Middle Vistula River section and does not have a continuous range. Moreover, in western Europe, this taxon was noticed stratigraphically slightly lower, close to the base of the Belemnitella langei Zone (Koch, 1977; Hart et al., 1989; Schönfeld, 1990).

In the "Inoceramus altus" inoceramid Zone is the FO of Bolivinoides sp., which posseses two parallel median rows of tubercles. This is probably a transitional form between Bolivinoides miliaris and $B$. draco. Bolivinoides draco, which is characterized by two very distinctive, well-developed, paralle median ribs derived from the fusion of the inner ornamental lobes, has been recorded in this site in the lower Upper Maastrichtian, in the Hoploscaphites constrictus Ivivenis Zone (Dubicka and Peryt, 2016), above the interval reported in this paper. In the upper part of the Piotrawin section, i.e. in the "Inoceramus" inkermanensis inoceramid Zone, two important foraminiferal events are observed: the FO of Bolivina decurrens and LO of Globorotalites emdyensis (= G. hiltermanni). Both these taxa also occur throughout the Sadkowice and Sadkowice North successions. The FO of Bolivina decurrens and LO of G. hiltermanni were described at Kronsmoor (Schönfeld, 1990) in the peterssoni/hiltermanni Zone i. e. in the uppermost part of the Micraster grimmensis/Cardiaster granulosus Zone. In Kronsmoor the FO of $B$. decurrens is noted just below the LO of $G$. emdyensis (= G. hiltermanni), similarly as in the Piotrawin section. In eastern England, the LO of $G$. hiltermanni is placed very close to the boundary of the traditional Belemnitella mucronata and Belemnella lanceolata zones, thus in a similar stratigraphical position to the Kronsmoor and Piotrawin sections. Summarizing, the FO of $B$. decurrens and LO of $G$. emdyensis (= G. hiltermanni) seem to be stratigraphically important events between central and western Europe. The LO of G. emdyensis (= G. hiltermanni) slightly below the $B$. lanceolata Zone was also noted in the Saratov Region, Russia (Olferev et al., 2007).

The next important benthic foraminiferal bioevent in the succession studied is the FO of Neoflabellina reticulata. This event was regarded as an important foraminiferal proxy for the base of the Maastrichtian in European basins (Odin, 1996). In the Middle Vistula River section, $N$. reticulata first appears at the base of the Kłudzie section, which is located within Błaszkiewicz's (1980) Belemnella lanceolata Zone, and
Remin's (2012) Belemnella inflata Zone, i.e., within very high Upper Campanian. A very similar or slightly lower stratigraphical position of the event was recorded throughout Europe. In eastern England, the FO of $N$. reticulata was placed at the inferred base of the traditional Belemnella lanceolata Zone (Hart et al., 1989). Recent research has shown that the FO of $N$. reticulata is located beneath a marl seam (Sidestrand Marl), a short distance below the entry of a Belemnella assemblage belonging to Remin's inflata Zone (see Mortimore et al, 2001, fig. 4.32; Wood pers.comm., 2015). In the Kronsmoor section, it appears at the $254.90 \mathrm{~m}$ level (Schönfeld, 1990), close to level mb 605, which according to Remin's belemnite zonal scheme (Remin in Niebuhr et al., 2011) is also located within the highest Upper Campanian Belemnella inflata Zone. Figure 7 of Niebuhr et al. (2011), shows erroneously the FO of $N$. reticulata at F600. In eastern Europe, the FO of $N$. reticulata in the Belemnella lanceolata Zone was also recorded in the Vishnevoe section (Saratov Region - Olferev et al., 2007). The event therefore seems to be an important marker for stratigraphical correlation across Europe.

In conclusion, it is very likely that, except for the LO of Gavelinella clementiana and FO of Neoflabellina praereticulata, all of the other discussed benthic foraminiferal events are isochronous between western and central European basins. Thus they can serve as useful chronostratigraphic markers across Europe.

\section{TAXONOMIC COMMENTS}

Only the occurrences within the Middle Vistula River section are given in the descriptions which follow.

Superfamily Globotruncanacea Brotzen, 1942

Family Rugoglobigerinidae Subbotina, 1959

Genus Rugoglobigerina Brönnimann, 1952

Rugoglobigerina hexacamerata Brönnimann, 1952 (Fig. 3Da-Db)

Rugoglobigerina reicheli hexacamerata - Brönnimann, 1952: 23-25, pl. 2, figs. 10-12, fig. 8a-m.

Rugoglobigerina hexacamerata Brönnimann - Pessagno, 1967: 364-365, pl. 74, fig. 4, pl. 91, figs. 5-7.

Rugoglobigerina hexacamerata Brönnimann - Peryt, 1980: 84-85, pl. 22, figs. 6,7 .

Rugoglobigerina hexacamerata Brönnimann - Robaszynski et al., 1984: 282, pl. 49, fig. 8.

Rugoglobigerina hexacamerata Brönnimann - Gawor-Biedowa, 1992: 90-91, pl. 17, figs. 10-12.

D e s c ri p t i o n. - Test with very low to flat trochospire; equatorial periphery circular, lobate; axial periphery rounded; the last whorl consists of 6 chambers increasing very slowly in size as added, ultimate chamber very often smaller than penultimate one; wall covered by meridionally arranged rugosities except terminal 2 or 3 chambers which are commonly smooth; spiral sutures depressed, radial; umbilical sutures radial to slightly curved; umbilicus small, deep; primary aperture umbilical.

$\mathrm{R}$ e $\mathrm{m}$ a $\mathrm{rk} \mathrm{s}$. - It differs from $R$. pennyi in having a flat spiral side, six chambers increasing very slowly in size in the last whorl and a very low height/diameter ratio.

O c c u r r e n c e. - First appears in the Kłudzie section in the "Inoceramus" redbirdensis inoceramid Zone and ranges to 
the top of the analysed part of the Middle Vistula River succession.

\section{Rugoglobigerina milamensis Smith and Pessagno, 1973}

$$
\text { (Fig. 3Fa-Fb) }
$$

Rugoglobigerina milamensis - Smith and Pessagno, 1973: 56, pl. 24, figs. 4-7.

Rugoglobigerina milamensis Smith and Pessagno - Peryt, 1980: 86, pl. 22, figs. 1, 5, 9.

Rugoglobigerina milamensis Smith and Pessagno Robaszynski et al., 1984: 284, pl. 50, fig. 3.

Rugoglobigerina milamensis Smith and Pessagno Gawor-Biedowa, 1992: 91-92, pl. 17, figs. 13-15.

Rugoglobigerina milamensis Smith and Pessagno - Peryt and Dubicka, 2009, figs. 4, 7a-c, 9a-c.

D e s c r i p t i o n. - Test moderately trochospiral; equatorial periphery subcircular, lobate; chambers spherical to subspherical, slightly elongated axially in apertural view; 5 to 6 chambers in the last whorl increasing slowly in size; wall heavily ornamented with rugosities and costellae but ornamentation not clearly developed in a meridional pattern; primary aperture umbilical.

$\mathrm{R}$ e $\mathrm{m}$ a rks. $-R$. milamensis differs from $R$. pennyi in having a very highly convex spiral side.

O c c u r r e n c e. - First appears in the Kłudzie section in the "Inoceramus" redbirdensis inoceramid Zone and ranges to the top of the analysed part of the Middle Vistula River succession.

\section{Rugoglobigerina pennyi Brönnimann, 1952}

(Fig. 3Ga-Gb)

Rugoglobigerina rugosa pennyi - Brönnimann, 1952: 34, pl. 4, figs. $1-3$, figs $14 a-c, d-f, g-i$.

Rugoglobigerina pennyi Brönnimann - Smith and Pessagno, 1973: 57, pl. 24, figs. 1-3.

Rugoglobigerina pennyi Brönnimann - Peryt, 1980: 86-87, pl. 12, fig. 6, pl. 22, figs. 10, 11.

Rugoglobigerina pennyi Brönnimann - Robaszynski et al., 1984: 285, pl. 50, fig. 1.

Rugoglobigerina pennyi Brönnimann - Peryt and Dubicka, 2009, fig. 4: 11a-c.

D e s c ription. - Test low trochospiral, equatorial periphery lobate; 5 to 6 spherical chambers in the final whorl increasing gently in size; wall covered by meridionally arranged rugosities; sutures depressed, radial; primary aperture umbilical.

O c c u r r e n c e. - First appears in the Kłudzie section in the "Inoceramus" redbirdensis inoceramid Zone and ranges to the top of the analysed part of the Middle Vistula River succession.

Rugoglobigerina rugosa (Plummer, 1926)

(Fig. 3Ea-Eb)

Globigerina rugosa n.sp. - Plummer, 1926: 38, pl. 2, fig. 10a-d (fide Ellis et Messina, Cat. of Foram.).
Rugoglobigerina rugosa (Plummer) - Smith and Pessagno, 1973: 58-60, pl. 25, figs. 1-4.

Rugoglobigerina rugosa (Plummer) - Peryt, 1980: 87, pl. 22, figs. 2, 3, 4, 8.

Rugoglobigerina rugosa (Plummer) - Hart et al., 1981: 218, pl. 7.23 , figs. $7-9$.

Rugoglobigerina rugosa (Plummer) - Robaszynski et al., 1984: 288 , pl. 49, figs. $4 a-c, 6 a-c$.

Rugoglobigerina rugosa (Plummer) - Gawor-Biedowa, 1992: 92, pl. 17, figs. $8,9$.

D e s c r i p t i o n. - Test trochospiral, biconvex, spiral side moderately convex; equatorial periphery lobate, axial periphery broadly rounded; 4 to 5 globular chambers in the final whorl, increasing sharply in size as added; wall covered by meridionally arranged rugosities; umbilicus large, deep; primary aperture umbilical.

O c currence. - First appears in the Raj North and Solec sections in the Trochoceramus costaecus inoceramid Zone and ranges to the top of the analysed succession of the Middle Vistula River section.

Superfamily Nodosariacea Ehrenberg, 1838

Family Vaginulinidae Reuss, 1860

Genus Neoflabellina Bartenstein, 1948

Neoflabellina praereticulata Hiltermann, 1952

(Fig. 3N)

Neoflabellina praereticulata n. sp. - Hiltermann, 1952: 53, text-fig. 3.37.

Neoflabellina praereticulata Hiltermann - Pożaryska, 1954: 260-261, fig. 16.

Neoflabellina praereticulata Hiltermann - Hiltermann and Koch, 1962: 308, pl. 50, fig. 12.

Neoflabellina praereticulata Hiltermann - Koch, 1977: 57-58, pl. 14, figs. 11, 12.

Neoflabellina praereticulata Hiltermann - Hart et al., 1981: 212, pl. 7.20, fig. 2.

Neoflabellina praereticulata Hiltermann - Robaszynski et al., 1985, pl. 5, fig. 2.

Neoflabellina reticulata (Reuss) - Gawor-Biedowa, 1992: 58-59, pl. 8, fig. 11.

Neoflabellina reticulata (Reuss) - Peryt, 2000, pl. 1, fig. 13.

D e s c ri p t i o n. - Test large, palmate to deltoid in outline with parallel and flat sides; early chambers in a planispiral coil, rapidly becoming uniserial with clearly marked longitudinal symmetry; sutures raised and distinct; numerous short ridges between sutures; aperture terminal, radiate, on the neck.

$\mathrm{R}$ e $\mathrm{m}$ a r k s. $-N$. praereticulata differs from $N$. reticulata in lacking connections between sutures and ridges occurring in the test surface resulting in lack of checked ornamentation.

Occurrence. - First appears at Łopoczno in the Sphaeroceramus pertenuiformis inoceramid Zone and ranges to the top of the analysed succession of the Middle Vistula River section.

Neoflabellina reticulata (Reuss, 1851)

(Fig. 30)

Flabellina reiculata n. sp. - Reuss, 1851: 30, pl. 1, figs. 22a-c (fide Ellis et Messina, Cat. of Foram.).

Neoflabellina reticulata (Reuss) - Pożaryska, 1954: 259, fig. 14. 
Neoflabellina reticulata (Reuss) - Hiltermann and Koch, 1962: 309 , pl. 50, figs. $13,14$.

Neoflabellina reticulata (Reuss) - Koch, 1977: 58, pl. 14, figs. 9, 10.

Neoflabellina reticulata (Reuss) - Hart et al., 1981: 212, pl. 7.20 , fig. 3 .

Neoflabellina reticulata (Reuss) - Robaszynski et al., 1985, pl. 5 , fig. 3 .

Neoflabellina reticulata (Reuss) - Peryt, 1988, pl. 11.

Neoflabellina reticulata (Reuss) - Schönfeld, 1990: 74-75, pl. 2, fig. 12.

Neoflabellina reticulata (Reuss) - Dubicka and Peryt, 2011, fig. $5 \mathrm{~W}$.

D e s c r i p t i o n. - Test large, palmate to deltoid in outline with parallel and flat sides; early chambers in a planispiral coil, rapidly becoming uniserial with clearly marked longitudinal symmetry; distinct and raised sutures and numerous shor ridges extending between sutures and approximately perpendicular to them, form characteristic reticulate ornamentation; aperture terminal, radiate, on the neck.

$\mathrm{R}$ e $\mathrm{m}$ a r k s. $-N$. reticulata differs from $N$. praereticulata in possessing short ridges connected with the sutures, resulting in reticulate ornamentation.

Occurrence. - First appears at the base of the Kłudzie section in the Belemnella inflata Zone and ranges to the top of the analysed part of the succession.

Superfamily Bolivinacea Glaessner, 1937

Family Bolivinidae Loeblich and Tappan, 1964

Genus Bolivina d'Orbigny, 1839

Bolivina decurrens (Ehrenberg, 1854)

(Fig. 3I, J)

Grammostomum? decurrens - Ehrenberg: 22, pl. 30, fig. 17 (fide Ellis et Messina, Cat. of Foram.).

Bolivina decurrens (Ehrenberg) - Hiltermann and Koch, 1962: 313, pl. 51, figs. 18, 19.

Bolivina decurrens (Ehrenberg) - Hofker, 1966: 39, pl. 5, fig. 40 ; p. 59, pl. 10, figs. 76,102 ; p. 73 , pl. 12 , fig. 26

Bolivina decurrens (Ehrenberg) - Koch, 1977: 59, pl. 14, figs. 7, 8.

Bolivina decurrens (Ehrenberg) - Peryt, 1988, pl. 2, fig. 14. Bolivina decurrens (Ehrenberg) - Gawor-Biedowa, 1992: 94-95, pl. 17, figs. 3, 4.

Coryphostoma decurrens (Ehrenberg) - Peryt, 2000, pl. 1, figs. 6,7 .

Bolivina decurrens (Ehrenberg) - Dubicka and Peryt, 2012a, fig. $4 \mathrm{~A}-\mathrm{C}$

D e s c r i p t i o n. - Test biserial, free, elongate and compressed; outline view of the text distinctly indented; margins acute and spinose. The aperture sub-terminal, elongated elliptical slit.

O c c u r r e n c e. - First appears in the middle part of the Piotrawin section in the "Inoceramus" inkermanensis inoceramid Zone and ranges to the top of the analysed part of the succession.
Bolivina incrassata Reuss, 1851

(Fig. 3K-M)

Bolivina incrassata n. sp. - Reuss, 1851: 45, pl. 4, fig. 13 (fide Ellis et Messina, Cat. of Foram.).

Bolivina incrassata Reuss - Hiltermann and Koch, 1962: 312, pl. 51 , figs. $14,15$.

Bolivina incrassata Reuss - Hofker, 1966: 39, pl. 5, fig. 42, p. 59, pl. 10, figs, 90, 91 .

Bolivina incrassata Reuss - Koch, 1977: 54, pl. 14, figs. 5, 6.

Bolivina incrassata Reuss - Robaszynski et al., 1985, pl. 5, fig. 7.

Bolivina incrassata Reuss - Schönfeld, 1990: 76-77, pl. 2 , figs. 18, 19.

Bolivina incrassata Reuss - Gawor-Biedowa, 1992: 95-96, pl. 19, figs. 1-3.

Coryphostoma incrassata (Reuss) - Peryt, 2000, pl. 1, figs. 1, $2,11,12$

Description. - Test biserial, free, slightly compressed with entire outline and sub-rounded periphery. Aperture an elongated elliptical slit extending from basal suture to terminal position of the final chamber.

Remarks. - Bolivina incrassata differs from $B$. decurrens in lacking indented, acute and spinose margins.

$\mathrm{O}$ c c u r r e n c e. - First appears in the Dorotka N section in the upper part of the Bostrychoceras polyplocum ammonite Zone and ranges to the top of the studied succession.

Genus Bolivinoides Cushman, 1927 Bolivinoides miliaris Hiltermann et Koch, 1950 (Fig. 3P)

Bolivinoides draco (Marsson) miliaris n. subsp. - Hiltermann and Koch, 1950: 604-606, text-figs. 2-4, no. 26, 32-34, 39-41, 46-48; text-fig. 5, no. 39a-c.

Bolivinoides draco miliaris Hiltermann and Koch - Pożaryska, 1954: 254, fig. 4.

Bolivinoides draco miliaris Hiltermann and Koch - Hiltermann and Koch, 1962: 317, pl. 46, fig. 9.

Bolivinoides draco miliaris Hiltermann and Koch - Koch, 1977: $56-57$, pl. 12, fig. 4.

Bolivinoides miliaris Hiltermann and Koch - Hart et al., 1981: 182, pl. 7.5 , fig. 3 .

Bolivinoides australis Edgell - Robaszynski et al., 1985, pl. 6, fig. 5.

Bolivinoides miliaris Hiltermann and Koch - Gawor-Biedowa, 1992: 103-104, pl. 20, fig. 6

D e s c ription. - Test robust, kite-shaped in outline, compressed to an elongated oval shape in cross section, 5 to 6 ornamental lobes. Early part of the test ornamented by numerous short tubercles and nodules.

$\mathrm{R}$ e $\mathrm{m}$ a r k s. - In the upper part of the Sphaeroceramus pertenuiformis inoceramid Zone appear forms which differ from $B$. miliaris in possessing two parallel median rows of tubercles. They are probably transitional forms from $B$. miliaris to $B$. draco (Fig. 3Q, R). 
O c c u r r e n c e. - First appears in the Dorotka N section in the upper part of the Bostrychoceras polyplocum ammonite Zone and ranges to the top of the studied succession.

Superfamily Chilostomellacea Brady, 1881

Family Globorotalitidae Loeblich and Tappan, 1964

Genus Globorotalites Brotzen, 1942

Globorotalites emdyensis Vasilenko, 1961

(Fig. 4Aa-Ac, Ca-Cc)

Globorotalites emdyensis n.sp. - Vasilenko, April 1961: 60-61, pl. 10, figs. 3a, b, w, 4a, b, w.

Globorotalites hiltermanni n. sp. - Kaever, September 1961: 418-419, pl. 20, fig. 1a-c.

Globorotalites hiltermanni Kaever - Hart et al., 1981: 198, pl. 7.13, figs. 10, 11.

Globorotalites hiltermanni Kaever - Schönfeld, 1990: 96-97, pl. 5, figs. 1-3.

Globorotalites emdyensis Vasilenko - Gawor-Biedowa, 1992: 150-151, pl. 32, figs. 1-3.

Globorotalites hiltermanni Kaever - Peryt, 2000, pl. 2, figs. 7, 8, 10, 11.

Globorotalites hiltermanni Kaever - Dubicka and Peryt, 2012a, fig. 4D12, E1E2.

Description. - Test trochospiral, planoconvex to biconvex, spiral side slightly to moderately convex; umbilical side convex, looks like a low cone with a wide base; periphery with poreless carina; 7 to 9 chambers enlarging gradually in the last whorl; sutures oblique, limbate and elevated on the spiral side; radial, curved and slightly depressed on the umbilical side; surface smooth; low and slitlike interiomarginal aperture with distinct murus reflectus on the umbilical side.

$\mathrm{R}$ e $\mathrm{m}$ a r k s. - It differs from G. michelinianus in having a biconvex test and limbate, raised sutures on the spiral side. In 1961 Kaever and Vasilenko independently described two new species of Globorotalites: Globorotalites hiltermanni from northern Germany and G. emdyensis from the Mangyshlak peninsula, Kazakhstan. Gawor-Biedowa (1992) already suggested that the two species were conspecific. However, because she did not see the original paper with the description of $G$. hiltermanni she was unable to form a judgement regarding priority. After comparison of the original figures of the holotypes, the descriptions of the two species and their variability, in view of the fact that the two taxa have the same stratigraphical range we came to the conclusion that they represent one species. Because the paper by Vasilenko was published in April 1961 while the paper by Kaever was published in September 1961, the name Globorotalites emdyensis has priority.

O c c u r r e n c e. - First appears in the Dorotka section in the Cataceramus subcompressus inoceramid Zone and in the Bostrychoceras polyplocum ammonite Zone and ranges to the upper part of the "Inoceramus" inkermanensis Zone.

Globorotalites michelinianus (d'Orbigny, 1840) (Fig. 4Da-Dc)

Rotalina micheliniana n. sp. - d'Orbigny, 1840: 31-32, pl. 3, figs. 1-3 (fide Ellis et Messina, Cat. of Foram.).

Globorotalites michelinianus (d'Orbigny) - Hart et al., 1981: 200, pl. 7.14, figs. $1,2$.
Globorotalites michelinianus (d'Orbigny) - Gawor-Biedowa and Witwicka, 1984: 285-286, pl. 99, figs. 1, 2.

D e s c r i p t i o n. - Test conical; spiral side flat to slightly concave, umbilical side strongly convex; $5-7$ chambers in the last whorl; surface smooth; periphery with poreless carina; chambers on the umbilical side enlarging gradually in height; the last (highest) chamber forming the peak of the cone; sutures curved and slightly depressed on the spiral side, radial and flat, almost invisible on the umbilical side; pseudoumbilicus small and shallow; low and slitlike interiomarginal aperture on the umbilical side.

O c c u r r e n c e. - Noted from the bottom of the studied succession up to the middle part of the Didymoceras donezianum ammonite Zone.

\section{Family Osangulariidae Loeblich and Tappan, 1964 Genus Osangularia Brotzen, 1940 \\ Osangularia navarroana (Cushman, 1938)}

(Fig. 4Ba-Bb, F)

Pulvinulinella navarroana n. sp. - Cushman, 1938: 66, pl. 11, figs. $5 \mathrm{a}-\mathrm{c}$.

Osangularia navarroana (Cushman) - Hart et al., 1981: 212, pl. 7.20 , figs. 7,8

Osangularia cordieriana navarroana (Cushman) - Schönfeld, 1990: 98-99, pl. 4, figs. 17-19.

Osangularia navarroana (Cushman) - Gawor-Biedowa, 1992: 152, pl. 33, figs. 1-3.

Osangularia navarroana (Cushman) - Peryt, 2000, pl. 2, figs. 1-3.

D e s c r i p t i o n. - Test trochospiral, biconvex with more convex spiral and much less convex umbilical side; flush margin outline, periphery circular and sharply ended; test surface smooth; aperture areal, elongated slit located on the flat chamber surface on the involute side.

O c c u r r e n c e. - First appears in the upper part of the Wola Pawłowska section in the Sphaeroceramus pertenuiformis inoceramid Zone and ranges to the top of the studied succession.

Family Gavelinellidae Hofker, 1956

Genus Angulogavelinella Hofker, 1957

Angulogavelinella gracilis (Marsson, 1878)

(Fig. 4Ea-Ec)

Discorbina gracilis n. sp. - Marsson, 1878: 166, pl. 4, fig. 34 (fide Ellis et Messina, Cat. of Foram.).

Pseudovalvulineria gracilis (Marsson) - Pożaryska, 1954: 267, fig. 26.

Angulogavelinella gracilis (Marsson) - Hofker, 1957: 366, text-figs. 419, 420.

Angulogavelinella bettenstaedti Hofker - Schönfeld, 1990: 104-105, pl. 5, figs. 7-9.

Angulogavelinella gracilis (Marsson) - Gawor-Biedowa, 1992: 162-163, pl. 34, figs. 1-3.

Angulogavelinella gracilis (Marsson) - Peryt, 2000, pl. 2, figs. 4-6.

Angulogavelinella gracilis (Marsson) - Dubicka and Peryt, 2012a, fig. 4G, H1-2. 
D e s c r i p t i o n. - Test low trochospiral, biconvex, with almost flush margin outline. On the spiral smooth side the last whorl is depressed and the central part of the test is raised. On the umbilical and involute side of the test sutures are very strongly raised, broad, prominent and curved back to the periphery.

$\mathrm{R}$ e m a r k s. - Early forms of $A$. gracilis occurring in the upper part of Łopoczno succession possess a flat spiral side of the test.

Occurrence. - First appears at the base of the Łopoczno section in the Sphaeroceramus pertenuiformis inoceramid Zone and ranges to the top of the studied succession. The species is very rare in the "Inoceramus" inkermanensis Zone.

Genus Gavelinella Brotzen, 1942

Gavelinella clementiana (d'Orbigny, 1840)

$$
\text { (Fig. 4Ga-Gc) }
$$

Rosalina clementiana - d'Orbigny, 1840: 37, pl. 3, figs. 23-25 (fide Ellis et Messina, Cat. of Foram.).

Stensioeina annae n. sp. - Pożaryska, 1954: 265-267, figs. 24, 25.

Stensioeina annae Pożaryska - Witwicka, 1958: 207, pl. 13, fig. $24 a-c$.

Stensioeina annae Pożaryska - Bieda, 1958: 52, fig. 20a-c. Gavelinella clementiana (d'Orbigny) - Hart et al., 1981: 194 pl. 7.11, figs. 1-3.

Stensioeina clementiana (d'Orbigny) - Robaszynski et al., 1985, pl. 4, fig. 2.

Gavelinella clementiana (d'Orbigny) - Schönfeld, 1990: 105-106, pl. 5, figs. 10-12.

Stensioeina clementiana (d'Orbigny) - Gawor-Biedowa, 1992: 158-159, pl. 39, figs. 4-6.

Description. - Test low trochospiral, with flat or slightly depressed spiral side and convex umbilical side, margin bluntly rounded. Characteristic ornamentation (numerous ridges and tubercles) occurs on both sides of the test or only on umbilical side.

Oc currence. - Noted in the Dorotka sction in the Cataceramus subcompressus inoceramid Zone. It is widely known in distinctly older strata, at least from the lower Campanian.

\section{Gavelinella monterelensis (Marie, 1941)}

(Fig. 4Ha-Hc)

Anomalina monterelensis n. sp. - Marie, 1941: 243, pl. 37, fig. 432a-c.

Gavelinopsis monterelensis (Marie) - Hofker, 1966: 29, pl. 3, fig. 60.

Gavelinella monterelensis (Marie) - Hart et al., 1981: 196, pl. 7.12, figs. 1-3.

Gavelinella monterelensis (Marie) - Robaszynski et al., 1985, pl. 5, fig. 5a-b.
Gavelinella monterelensis (Marie) - Gawor-Biedowa, 1992: 168-169, pl. 36, figs. 1, 2.

Gavelinella monterelensis (Marie) - Dubicka and Peryt, 2012a, fig. 4F1-3.

D e s cription. - Test very low trochospiral, almost planispiral, biconvex with almost flush margin outline. Periphery circular with imperforate "keel-like" structure. Test biumbonate with umbilical boss more distinct and raised than spiral side boss; numerous chambers (from 12 to 14 in the final whorl).

O c c u r r e n c e. - Noted from the bottom of the studied succession up to basal part of the "Inoceramus" altus inoceramid Zone.

\section{SUMMARY}

Planktonic foraminifera of the Upper Campanian-Lower Maastrichtian of the Middle Vistula River section (comprising eight inoceramid bivalve zones of Walaszczyk, 2004), are represented by cosmopolitan taxa, with rather moderate chronostratigraphic potential. Planktonic foraminifera taxa that are important biostratigraphical markers elsewhere, particularly in the Tethyan Realm, do not occur, and thus direct correlation with the standard planktonic foraminiferal zonation and distant regions are impossible/difficult. However, we were able to recognize one significant planktonic foraminiferal bioevent, i.e. the FO's of Rugoglobigerina milamensis, $R$. hexacamerata and $R$. pennyi, dated to the uppermost "I." redbirdensis inoceramid Zone. This level, as defined by inoceramids (Walaszczyk, 2004), is very close to the Campanian/Maastrichtian boundary. This event may be a good proxy for this stage boundary in temperate regions.

Benthic foraminifera in the studied succession are generally abundant and well-preserved. In the course of this investigation we identified the following twelve benthic foraminiferal bioevents in ascending stratigraphical order:

FO of Globorotalites emdyensis (= G. hiltermanni)

LO of Gavelinella clementiana

LO of Globorotalites michelinianus

LO of Globorotalites emdyensis (= G. hiltermanni)

FO of Bolivina incrassata

FO of Bolivinoides miliaris

FO of Neoflabellina praereticulata

FO of Angulogavelinella gracilis ( $=$ A. bettenstaedti)

LO of Gavelinella monterelensis

FO of Osangularia navarroana

FO of Bolivina decurrens

FO of Neoflabellina reticulata

Apart from the LO of $G$. clementiana and FO of $N$. praereticulata, which seem to be more diachronous, all of the other events are located in very similar stratigraphical positions in the Middle Vistula River section, in northern Germany (Lägerdorf-Kronsmoor), eastern England and in some eastern European sections. Accordingly they can serve as important markers for stratigraphical correlations across Europe.

Acknowledgements. We are very grateful to C. Wood, I. Walaszczyk and L. Kopaevich for many helpful remarks that markedly improved the manuscript. 


\section{REFERENCES}

Akimets, V.S., 1961. Stratigrafiya i foraminifery verkhnemelovykh otlozheniy Belorusi (in Russian). Akad. Nauk. Bel. SSR, Inst. Geol. Nauk, ser. paleont. strat., 3: 1-245.

Arz, J.A., Molina, E., 2001. Planktic foraminiferal quantitative analysis across the Campanian/Maastrichtian boundary at Tercis les Bains (France). Developments in Palaeontology and Stratigraphy, 19: 338-348.

Bailey, H., Hart, M.B., 1979. The correlation of the Early Senonian in Western Europe using Foraminiferida. Aspekte der Kreide Europas, IUGS, 6: 159-169.

Bailey, H.W., Hart, M.B., Swiecicki, A., 2009. Evolutionary lineages of benthic foraminifera in the chalk seas of N.W. Europe and their application to problem solving. SEPM Special Publication, 93: 233-249.

Bé, A.W.H., 1977. An ecological, zoogeographic and taxonomic review of Recent planktonic foraminifera. In: Oceanic Micropaleontology (ed. A.T.S. Ramsey). Academic Press, London.

Benyamovskiy, V.N., Alekseev, A.S., Ovechkina, M.N., Vishnevskaya, V.S., Podgaetskii, A.V., Pronin, V.G., 2012. Upper Campanian-lower Maastrichtian sections of the northwestern Rostov region. Article 1. Description, paleontological assemblages, and lithobiostratigraphy. Stratigraphy and Geological Correlation, 20: 346-379.

Bieda, E., 1958. Index foraminifers and the age of the Mielnik Chalk (Eastern Poland) (in Polish with English summary). Biuletyn Instytutu Geologicznego, 121: 17-89.

Błaszkiewicz, A., 1966. Remarks on Campanian and Maastrichtian stratigraphy of the Middle Vistula River Valley, Central Poland (in Polish with English summary). Kwartalnik Geologiczny, 10 (4): 1060-1071.

Błaszkiewicz, A., 1980. Campanian and Maastrichtian ammonites of the Middle Vistula River valley, Poland: a stratigraphic and paleontological study. Prace Instytutu Geologicznego, 92: 1-63.

Bolli, H.M., 1966. Zonation of Cretaceous to Pliocene marine sediments based on planktonic foraminifera. Boletin Informativo Asociacion Venezolana de Geologia, Mineria y Petroleo, 9: 1-32.

Bronnimann, H., 1952. Globigerinidae from the Upper Cretaceous (Cenomanian-Maestrichtian) of Trinidad. B. W. I. Bulletins of American Paleontology, 34: 1-70.

Burnett, J.A., Hancock, J.M., Kennedy, W.J., Lord, A.R., 1992. Macrofossil, planktonic foraminiferal and nannofossil zonations at the Campanian/Maastrichtian boundary. Newsletters on Stratigraphy, 27: 157-172.

Caron, M., 1985. Cretaceous planktic foraminifera. In: Plankton Stratigraphy (eds. H.M. Bolli, J.B. Saunders and K. Perch-Nielsen ): 17-86. Cambridge University Press.

Caron, M., Homewood, P., 1983. Evolution of the early planktic foraminifera. Marine Micropaleontology, 7: 453-462.

Christensen, W.K., Hancock, J.M., Peake, N.B., Kennedy, W.J., 2000. The base of the Maastrichtian. Bulletin of the Geological Society of Denmark, 47: 81-85.

Cushman, J., 1938. Some new species of rotaliform foraminifera from the American Cretaceous. Contributions from the Cushman Laboratory for Foraminiferal Research, 14: 66-71.

Dadlez, R., Marek, S., Pokorski, J., 2002. Mapa geologiczna Polski bez utworów kenozoiku (Geological map of the Poland without Cainozoic deposits) 1:1 000 000. Ministerstwo Środowiska i Państwowy Instytut Geologiczny: Wydawnictwo Kartograficzne Polskiej Agencji Ekologicznej, Warszawa.

Dubicka, Z., 2015. Benthic foraminiferal biostratigraphy of the lower and middle Campanian of the Polish Lowlands and its application for interregional correlation. Cretaceous Research, 56: 491-503.

Dubicka, Z., Peryt, D., 2011. Integrated biostratigraphy of Upper Maastrichtian chalk at Chełm (SE Poland). Annales Societatis Geologorum Poloniae, 81: 185-197.
Dubicka, Z., Peryt, D., 2012a. Latest Campanian and Maastrichtian palaeoenvironmental changes: implications from an epicontinental sea (SE Poland and western Ukraine). Cretaceous Research, 37: 272-284.

Dubicka, Z., Peryt, D., 2012b. The Lower/Upper Maastrichtian boundary interval in the Lublin Syncline (SE Poland, Boreal Realm): new insight into foraminiferal stratigraphy. Newsletters on Stratigraphy, 45: 139-150.

Dubicka, Z., Peryt, D., 2014. Classification and evolutionary interpretation of late Turonian-early Campanian Gavelinella and Stensioeina (Gavelinellidae, benthic foraminifera) from western Ukraine. Journal of Foraminiferal Research, 44: 151-176.

Dubicka, Z., Peryt, D., 2016. Bolivinoides (benthic foraminifera) from the Upper Cretaceous of Poland and western Ukraine: taxonomy, evolutionary changes and stratigraphic significance. Journal of Foraminiferal Research.

Ellis, B.F., Messina, A.R., 1940-1983. Catalogue of Foraminifera. American Museum of Natural History, New York.

Gawor-Biedowa, E., 1992. Campanian and Maastrichtian Foraminifera from the Lublin Upland, Eastern Poland. Palaeontologia Polonica, 52: 3-187.

Gawor-Biedowa, E., Witwicka, E., 1984. Fauna - Bezkręgowce. Typ Protista. In: Budowa Geologiczna Polski, 3, Atlas skamieniałości przewodnich i charakterystycznych, 2c, Mezozoik, Kreda: 187-308.

Gaździcka, E., 1978. Calcareous nannoplankton from the uppermost Cretaceous and Paleogene deposits of the Lublin Upland. Acta Geologica Polonica, 23: 335-375.

Hardenbol, J., Thierry, J., Farrey, M.B., Jacquin, T., Graciansky, P.-Ch., Vail, P.R., 1998. Mesozoic and Cenozoic sequence chronostratigraphic framework of European Basins. SEPM Special Publication, 60: 3-13.

Hart, M.B., Swiecicki, T., 2003. Stratigraphy of Maastrichtian Foraminiferida from the United Kingdom; the Maastrichtian of Norfolk. Netherlands Journal of Geosciences/Geologie en Mijnbouw, 82: 233-245.

Hart, M.B., Bailey, H.W., Fletcher, B.N., Price, R.J., Swiecicki, A., 1981. Cretaceous. In: Stratigraphical Atlas of Fossil Foraminifera (eds. D.G. Jenkins and J.W. Murray): 149-227. E. Horwood, Chichester.

Hart, M.B., Bailey, H.W., Crittenden, S., Fletcher, B.N., Price, R.J., Swiecicki, A., 1989. Cretaceous. In: Stratigraphical Atlas of Fossil Foraminifera (eds. D.G. Jenkins and J.W. Murray): 273-371. Second Edition, E. Horwood, Chichester,.

Hemleben, C., Spindler, M., Anderson, O.R., 1989. Modern Planktonic Foraminifera. Springer, Heidelberg.

Hiltermann, H., 1952. Stratigraphische Fragen des Campan und Maastricht unter besonderer Berücksichtigung der Mikropaläontologie. Geologisches Jahrbuch, 67: 47-66.

Hiltermann, H., Koch, W., 1950. Taxonomie und Vertikalverbreitung von Bolivinoides-Arten im Senon Nordwestdeutschlands. Geologisches Jahrbuch, 64: 595-632.

Hiltermann, H., Koch, W., 1962. Oberkreide des nördlichen Mitteleuropa. In: Leitfossilien der Mikropaläontologie. Gebrüder Borntraeger, Berlin.

Hofker, J., 1952. Correlation of the Tuff Chalk of Maestricht (type Maestrichtian) with the Danske Kalk of Denmark (type Danian), the stratigraphic position of the type Montian, and the planktonic foraminiferal faunal break. Journal of Paleontology, 36: 1051-1089.

Hofker, J., 1956. Die Globotruncanen von Nordwest-Deutschland und Holland. Neues Jahrbuch für Geologie und Paläontologie, Abhandlungen, 103: 312-340.

Hofker, J., 1957. Foraminiferen der Oberkreide von Nordwestdeutschland und Holland. Geologisches Jahrbuch, Beihefte, 27: 7-464.

Hofker, J., 1966. Maestrichtian, Danian and Paleocene Foraminifera. Palaeontographica Suppl., 10: 1-376. 
Kaever, M., 1961. Morphologie, Taxonomie und Biostratigraphie von Globorotalites und Conorotalites (Kreide-Foram.). Geologisches Jahrbuch, 78: 387-438.

Keutgen, N., Remin, Z., Walaszczyk, I., 2012. Early representatives of the belemnite genus Belemnella (Cephalopoda) from the uppermost Campanian-Lower Maastrichtian of the Middle Vistula River section, central Poland. Acta Geologica Polonica, 62: $535-559$

Koch, W., 1977. Stratigraphie der Oberkreide in Nordwestdeutschland (Pompeckjsche Scholle). Teil 2. Biostratigraphie in der Oberkreide und Taxonomie von Foraminiferen. Geologisches Jahrbuch, A 38: 11-123.

Kongiel, R., 1962. On belemnites from Maastrichtian, Campanian and Santonian sediments in the Middle Vistula valley (Central Poland). Prace Muzeum Ziemi, 5: 3-148.

Kutek, J., Głazek, J., 1972. The Holy Cross area, Central Poland, in the Alpine cycle. Acta Geologica Polonica, 22: 603-651.

Loeblich, A.R., Jr., Tappan, H., 1987. Foraminiferal Genera and their Classification. Van Nostrand Reinhold, New York.

Machalski, M., 2012. Stratigraphically important ammonites from the Campanian-Maastrichtian boundary interval of the Middle Vistula River section, central Poland. Acta Geologica Polonica, 62: $91-116$

Marie, P., 1941. Les foraminiféres de la craie a Belemnitella mucronata du Bassin de Paris. Mémoires du Muséum National d'Histoire Naturelle, N.S., 12: 1-296.

Mortimore, R.N., Wood, C.J., Gallois, R.W. 2001. British Upper Cretaceous Stratigraphy. Geological Conservation Review Series, No. 23. Joint Nature Conservation Committee, Peterborough.

Narkiewicz, M., Dadlez, R., 2008. Geological regional subdivision of Poland: general guidelines and proposed schemes of sub-Cenozoic and sub-Permian units (in Polish with English summary). Przegląd Geologiczny, 56: 391-397.

Niebuhr, B., Hampton, M.J., Gallagher, L.T., Remin, Z., 2011. Integrated stratigraphy of the Kronsmoor (northern Germany), a reference point for the base of the Maastrichtian in the Boreal Realm. Acta Geologica Polonica, 61: 193-214.

Odin, G.S. (compiler) 1996. Definition of a Global Boundary Stratotype Section and Point for the Campanian and Maastrichtian boundary. Bulletin de I'Institut Royal des Sciences Naturelles de Belgique, 66: 111-117.

Odin, G.S., 2001. Numerical age calibration of the Campanian-Maastrichtian succession at Tercis les Bains (Landes, France) and in the Bottaccione section (Italy). Developments in Palaeontology and Stratigraphy, 19: 775-782.

Odin, G.S., Lamaurelle, M.A., 2001. The global Campanian-Maastrichtian stage boundary. Episodes, 24: 229-238.

Odin, G.S., the Maastrichtian Working Group Members, 2001. The Campanian-Maastrichtian boundary: definition at Tercis (Landes, SW France) - principle, procedure, and proposal. Developments in Palaeontology and Stratigraphy, 19: 820-833.

Olferev, A.G., Beniamovski, V.N., Vishnevskaya, V.S., Ivanov, A.V., Kopaevich, L.F., Pervushov, E.M., Seltser, V.B., Tesakova, E.M., Kharitonov, V.M., Shcherbinina, E.A., 2007. Upper Cretaceous deposits in the northwest of Saratov oblast, Part 1: Litho- and biostratigraphic analysis of the Vishnevoe section. Stratigraphy and Geological Correlation, 15: 610-655.

Pawlowski, J., Holzmann, M., Tyszka, J., 2013. New supraordinal classification of Foraminifera: Molecules meet morphology. Marine Micropaleontology, 100: 1-10.

Pérez-Rodríguez, I., Lees, J.A., Larrasoaña, J.C., Arz, J.A., Arenillas, I., 2012. Planktonic foraminiferal and calcareous nannofossil biostratigraphy and magnetostratigraphy of the uppermost Campanian and Maastrichtian at Zumaia, northern Spain. Cretaceous Research, 37: 100-126.

Peryt, D., 1980. Planktonic foraminifera zonation of the Upper Cretaceous in the Middle Vistula River Valley, Poland. Palaeontologia Polonica, 41: 3-101.
Peryt, D., 1988. Paleoecology of middle and late Cretaceous foraminifers from the Lublin Upland (SE Poland). Révue de Paléobiologie, 2 (vol. spec.): 311-321.

Peryt, D., 2000. On the age of siliceous chalk in the Piotrawin Quarry, Middle Vistula River Valley, Central Poland (in Polish with English summary). Biuletyn Państwowego Instytutu Geologicznego, 393: 81-94.

Peryt, D., Dubicka, Z., 2009. Palaeoenvironmental changes in the Early Maastrichtian of the Nida trough (Southern Poland): foraminiferal evidence. Grzybowski Foundation Special Publication, 15: 101-108.

Pessagno, E., 1967. Upper Cretaceous planktonic foraminifera from the western Gulf Coastal Plain. Palaeontographica Americana, 37: 245-445.

Pożaryska, K., 1954. The Upper Cretaceous index Foraminifera from Central Poland (in Polish with English summary). Acta Geologica Polonica, 4: 249-276.

Pożaryska, K., Peryt, D., 1979. The Late Cretaceous and Early Paleocene foraminiferal "Transitional Province" in Poland. IUGS Series, A 6: 293-303.

Pożaryski, W., 1938. Senonstratigraphie im Durchbruch der Weichsel zwischen Rachów und Puławy in Mittelpolen (in Polish with German summary). Biuletyn Państwowego Instytutu Geologicznego, 6: 3-94.

Pożaryski, W., 1966. Cretaceous stratigraphy in the Włoszczowa Trough (in Polish with English summary). Kwartalnik Geologiczny, 10 (4): 1032-1046.

Pożaryski, W., 1974. Tektonika cz. 1. Niż Polski (in Polish). In Budowa geologiczna Polski (ed. W. Pożaryski): 2-34. Wyd. Geol., Warszawa.

Pożaryski, W., 1997. Tektonika powaryscyjska obszaru świętokrzysko-lubelskiego na tle struktury podłoża (in Polish). Przegląd Geologiczny, 45: 1265-1270.

Premoli Silva, I., Sliter, W.V., 1999. Cretaceous paleoceanography: evidence from planktonic foraminiferal evolution. GSA Special Paper, 332: 301-328.

Remin, Z., 2012. The Belemnella stratigraphy of the Campanian-Maastrichtian boundary: a new methodological and taxonomic approach. Acta Geologica Polonica, 62: 495-533.

Remin, Z., 2015. The Belemnitella stratigraphy of the Upper Campanian-basal Maastrichtian of the Middle Vistula section, central Poland. Geological Quarterly, 59 (4): 814-830.

Robaszynski, F., Caron, M., 1995. Foraminifčres planctoniques du Crétacé: Commentaire de la zonation Europe-Méditerranée. Bulletin de la Société géologique de France, 166: 681-692.

Robaszynski, F., Caron, M., Gonzalez Donoso, J.M., Wonders, A.A.H., 1984. Atlas of Late Cretaceous Globotruncanids. Revue de Micropaléontologie, 26: 145-305.

Robaszynski, F., Bless, M.J.M., Felder, P.J., Foucher, J.C., Legoux, O., Manivit, H., Meesen, J.P.M.T., Van der Tuuk, L.A., 1985. The Campanian-Maastrichtian boundary in the chalk facies close to the type-Maastrichtian area. Bulletin des Centres de Recherches Exploration-Production, Elf-Aquitaine, 9: 1-113.

Rozumeiko, S. V., 1978. Foraminifery verkhnemelovykh otlozhenii yugo-zapada vostochno-evropeiskoy platformy (in Russian). Naukova Dumka, Kiev.

Schulz, M-G., Ernst, G., Ernst, H., Schmid, F. 1984. Coniacian to Maastrichtian stage boundaries in the standard section for the Upper Cretaceous white chalk of NW Germany (Lägerdorf-Kronsmoor-Hemmoor): Definitions and proposals. Bulletin of the Geological Society of Denmark, 33: 203-215.

Schönfeld, J., 1990. Zur Stratigraphie und Ökologie bentischer Foraminiferen im Schreibkreide-Richtprofil von Lägerdorf/Holstein. Geologisches Jahrbuch Abhandlungen, 117: 3-151.

Smith, Ch.C., Pessagno, E.A., 1973. Planktonic foraminifera and stratigraphy of the Corsicana Formation (Maestrichtian), North Central Texas. Cushman Foundation for Foraminiferal Research, Special Report, 12: 1-68.

Świdrowska, J., 2007. Cretaceous in Lublin area - sedimentation and tectonic conditions (in Polish with English summary). Biuletyn Państwowego Instytutu Geologicznego, 422: 63-78. 
Vasilenko, V.P., 1961. Upper Cretaceous Foraminifera from the Mangyshlak peninsula (in Russian). Trudy VNIGRI, 171: 3-390.

Voigt, S., Wagreich, M., Surlyk, F., Walaszczyk, I., Uličný, D., Čech, S., Voigt, T., Wiese, F., Wilmsen, M., Niebuhr, B., Reich, M., Funk, H., Michalík, J., Jagt, J.W.M., Felder, P.J., Schulp, A.S., 2008. Cretaceous. In: Geology of Central Europe, Mesozoic and Cenozoic (ed. T. McCann), 2: 923-997. Geological Society, London.

Walaszczyk, I., 2004. Inoceramids and inoceramid biostratigraphy of the Upper Campanian to basal Maastrichtian of the Middle River section, central Poland. Acta Geologica Polonica, 54: 95-168.

Walaszczyk, I., 2012. Integrated stratigraphy of the Campanian-Maastrichtian boundary succession of the Middle Vistula River (central Poland) section; introduction. Acta Geologica Polonica, 62: 485-493.

Walaszczyk, I., Peryt, D., 1992. Inoceramid-foraminiferal biostratigraphy of the Turonian through Santonian deposits of the Middle Vistula Section, Central Poland. Zentralblatt für Geologie und Paläontologie, Teil I: 1501-1513.

Watkins, R.C., Veltkamp, C.J., 1994. Microevolution and migration of the benthonic foraminiferan Gavelinella pseudoexcolata (Kalinin, 1937) within the Upper Cretaceous (SantonianCampanian) of the Anglo-Paris Basin. Revue de Micropaléontologie, 37: 321-338.

Wilkinson, I.P., 2011. Foraminiferal biozones and their relationship to the lithostratigraphy of the Chalk Group of southern England. Proceedings of the Geologists' Association, 122: 842-849.

Witwicka, E., 1958. Upper Cretaceous micropaleontological stratigraphy of the Chełm borehole (in Polish with English summary). Biuletyn Instytutu Geologicznego, 121: 177-267.

Żelaźniewicz, A., Aleksandrowski, P., Buła, Z., Karnkowski, P.H., Konon, A., Oszczypko, N., Ślączka, A., Żaba, J., Żytko, K., 2011. Regionalizacja Tektoniczna Polski (in Polish). Komitet Nauk Geologicznych PAN, Wrocław. 